\title{
Drought Effects on Early Growth and Mortality of Three Oak Species in the Upper Rhine Valley
}

\author{
Sandrine Brèteau-Amores ${ }^{1,2}$ \\ ${ }^{1}$ Chair of Silviculture, University Albert-Ludwigs, Freiburg-im-Breisgau, Germany \\ ${ }^{2}$ Université de Lorraine, Université de Strasbourg, AgroParisTech, CNRS, INRA, BETA, Nancy, France \\ Email: sandrine.breteau-amores@inra.fr
}

How to cite this paper: Brèteau-Amores, S. (2018) Drought Effects on Early Growth and Mortality of Three Oak Species in the Upper Rhine Valley. American Journal of Climate Change, 7, 336-354. https://doi.org/10.4236/ajcc.2018.72020

Received: February 7, 2018

Accepted: June 26, 2018

Published: June 29, 2018

Copyright (c) 2018 by author and Scientific Research Publishing Inc. This work is licensed under the Creative Commons Attribution International License (CC BY 4.0).

http://creativecommons.org/licenses/by/4.0/

(c) (i) Open Access

\begin{abstract}
Pedunculate oak and sessile oak are important natural species in the Upper Rhine Valley. The increasing mortality of these oak species has been observed since the 1980s in this region, mainly due to severe droughts. Turkey oak is known to be highly productive and drought-resistant. The goal of this article is therefore to investigate the adaptability to drought of these three young oak species growing at the same site, and to show to what extent Turkey oak can be substituted for these native oak species. Stand measurements and retrospective analyses of radial growth were performed within the framework of the eight-year-old "Mooswald" afforestation experiment in order to determine stand volume, mortality and resistance/resilience to drought for each species. Turkey oak shows significantly higher stand volume and significantly lower mortality than sessile oak. Values of these two parameters for Turkey oak and sessile oak are not significantly different from those of pedunculate oak. However, Turkey oak is not more resistant to drought than the other oak species. Sessile oak has the highest mortality and the smallest stand volume, while pedunculate oak is the least resilient to drought. These results are only a trend that must be confirmed in older stand stages and investigation in young stands must continue, supported by better monitoring and improved tools.
\end{abstract}

\section{Keywords}

Forest, Climate Change, Case Study, Tree-Ring, Lloret Index

\section{Introduction}

Since the 1980s, the increasing mortality of sessile oak (Quercus petraea (Matt.) Liebl.) and especially pedunculate oak (Quercus robur L.) has been observed at many sites in the Upper Rhine Valley [1] [2] [3]. This can be explained by biotic 
factors (e.g., insect and fungal attacks), soil factors (e.g., water availability, nutrient supply, soil chemical properties, soil compaction), and mainly by climatic conditions such as severe droughts [2]. In the current context of climate change, this situation will continue to worsen. The climate has been changing since 1950 with an increase in temperature, a decrease in precipitation and an intensification of extreme events such as severe droughts, storms, fires [4]. More precisely, [5] demonstrated that drought will increase the vulnerability of the forests in the Upper Rhine Valley. Although pedunculate oak and sessile oak are declining at many sites in Europe [6], both are described as relatively drought-tolerant species [7] [8]. Nevertheless, their development under the future climate is still unclear. That is why the question of the substitution of these native oak species with more drought-adapted species such as Turkey oak (Quercus cerris L.) is studied here.

Pedunculate oak and sessile oak are economically and ecologically important natural species in the Upper Rhine Valley [9]. These deciduous species have mid-successional characteristics since they are light-demanding and have deeply penetrating taproots, as well as late successional species characteristics with their large reserves of acorns. Compared to sessile oak, pedunculate oak is more light-demanding and develops better on heavier soils in more continental climates, in wet lowlands and in damp areas close to streams and rivers, tolerating periodic flooding [10]. Nonetheless, since it favours more Atlantic climates, sessile oak is more drought-tolerant, growing on light and well-drained, often rocky soils generally found on slopes and hill tops. They also tolerate low soil pH [10]. The characteristics of Turkey oak are similar to those of sessile oak: a deciduous and pioneer species with a wide range of tolerance to varying light conditions, air pollution, drought and soil types [11]. Turkey oak prefers a cool microclimate and is vulnerable to severe winters [12]. This oak is described as a more drought-resistant species [13] than many of the native oak species studied [11], but it is also declining in vitality in some Mediterranean countries (natural distribution) such as Italy [14]. From the silvicultural standpoint, [15] described Turkey oak as being highly productive, with high vitality and wood quality on a poorly managed forest of 6 ha artificially established in 1890 in Prenzlau (Germany). This stand even reached the diameter and height level of the highest wood price class of sessile oak. Consequently, it can be assumed that Turkey oak would perform even better with suitable management. In addition, studies in Serbia confirmed that lack of thinning has a strong negative influence on the vitality of the trees [16].

Few studies [11] [13] [17] have investigated the silvicultural suitability of non-native Mediterranean oak species such as Turkey oak under central Europe site conditions. However, no study has yet compared Turkey oak with sessile or pedunculate oak. This project is thus the first to investigate the three oak species growing at the same site. In addition to this, very few studies have been done on the adaptation of young trees to drought [18] [19] [20]. Indeed, when dealing 
with young forest stand stages, the literature generally only focuses on seedlings [21] [22] [23] and no study exists concerning the analysis of radial growth on young trees (i.e. under 10 - 15 years old). The goal of this article is therefore to investigate the adaptability of different oak species to drought, comparing two native and one non-native species. First, stand measurements was performed within the framework of the "Mooswald" afforestation experiment. Then, retrospective analyses of radial growth were realized to compare the three oak species in terms of resistance (i.e., the ratio between the radial growth performance during and prior to the drought year), recovery (i.e., the ratio between the performance after (PostDr) and during the disturbance) and resilience (i.e., the ratio between the radial growth performance after and prior to the drought year). Compared to the native oak species (pedunculate oak and sessile oak), we determined: 1) whether or not the non-native Turkey oak shows higher stand volume within the first eight years after planting and less mortality in response to the severe drought of summer 2015; and 2) if Turkey oak is more resistant and more resilient to radial growth depressions in response to drought years (such as 2013 and 2015). This young afforestation provides information about the relative performance of the three oak species in the crucial establishment phase of forests.

\section{Methods}

\subsection{Study Site and Experimental Design}

The "Mooswald" experimental site is located $5 \mathrm{~km}$ west of Freiburg im Breisgau (Baden-Württemberg, Germany; $48^{\circ} 01$ North, $7^{\circ} 77$ East, elevation of $217 \mathrm{~m}$ above sea level). The experiment site was established in spring 2008 on former farmland (soil type: "pseudogley"). It covers an area of 2.8 ha containing 56 randomly-distributed plots, i.e., four plots for each of the 14 tree species planted. Each plot contains 156 regularly spaced trees $(1.5 \mathrm{~m}$ in the north-south direction and $2.0 \mathrm{~m}$ in the west-east direction) and measures $500 \mathrm{~m}^{2}$. Non-native tree species such as Turkey oak were also planted in this trial. This experiment thus provides the opportunity to compare native and non-native species, and mainly different oak species, growing at the same site. The main goal of this experiment was to investigate the adaptability of different tree species to natural (and possibly artificial) drought events during future decades. The "Mooswald" trial combines potential stress through changing water regimes and biotic stressors with drought. Indeed, severe waterlogging situations due to the near-surface groundwater table have periodically occurred at the "Mooswald" site [24] [25]. However, due to human activities (e.g., stream water rectification, water consumption by industry) and their consequences (e.g., climate change), the groundwater table has been decreasing for more than 100 years [25], from the ground surface to 10 $\mathrm{m}$ below at this time [26]. In addition, oak species suffer periodically from insect pests (caterpillars such as Thaumetopoea processionea).

\subsection{Measurements and Sampling Procedure}

All field data collection was performed during the second half of March 2016. 
Height and diameter were measured to characterise the volume of each tree species. Mortality was assessed. We defined a "buffer zone" that corresponded to a strip of two tree rows along the edge of each plot. These trees were excluded from the diameter and height measurements to avoid potential edge effects. The breast height was marked in the northerly direction on the bark with a lumber and marking crayon (Lyra, Germany). Trees with two stems were defined as forks when the stems had the same height and a similar Diameter at Breast Height $(\mathrm{DBH}) \pm 10 \%$ [27]. When the division started below $1.3 \mathrm{~m}$ aboveground, the two stems were considered as two different trees, and as one single tree when the division started above that height [28].

Mortality was assessed in all trees in May 2016. A tree was considered to be dead if it was missing, had no buds, a dry stem, and/or no leaves after bud burst. Diameter was measured at breast height ( $1.3 \mathrm{~m}$ above ground) in millimetres, using a manual calliper $(0-150 \mathrm{~mm})$. The final diameter was the average of a pair of measurements taken in two perpendicular hemispherical directions (north-south and west-east). In the case of forks (below or at breast height) or branch whorls at breast height, this pair of measurements were done at each stem of the fork and below and above the branch whorl, respectively. The final tree diameter was then calculated from the total average of all the pairs of measurements. A diameter class was defined each $10 \mathrm{~mm}$, from 10 (class 1) to more than $109 \mathrm{~mm}$ (class 10). Height was measured in metres using a Vertex IV (Haglöf Sweden) in two randomly selected trees per diameter class (i.e., an average of 14 trees per plot).

Concerning the sampling of increment cores, regular increment corers could not be used due to the small size of the trees since they could possibly cause extensive damage to stems. Thus, a small diameter increment borer (3-threading borer; Haglöf, Sweden) was used to collect increment cores with a reduced diameter ( $3 \mathrm{~mm}$ instead of the common $5 \mathrm{~mm}$ ), at $1.1 \mathrm{~m}$ aboveground so as to not disturb the stem at breast height for subsequent measurements. Damage was minimised on these young trees, sampling only one core per tree and avoiding drilling deeper than the pith of each stem. In the end, 96 increment cores were collected (i.e., eight cores per plot) along the north-south direction to avoid potential reaction wood (the main wind direction being west). These 96 trees were selected according to the following criteria: alive, largest diameter, straight (no forks, no branch whorls) and canopy-dominant (to avoid bias due to different social categories).

The sampled cores were stored in a cardboard box with corrugated cardboard inside to dry in the ambient air. They were marked with a colour point near the pith centre, making it possible to identify the species (one colour per species) and the bark-pith direction of the cores. After two weeks, cores were sanded and scanned at a high resolution of $1200 \mathrm{dpi}$ (picture saved in TIFF format). The tree-ring analysis was performed using Windendro ${ }^{\mathrm{TM}}$ software (version 2012a; Regent Instruments, Canada), resulting in a ring width curve for each tree. There were eight rings (from 2008 to 2015). Reference series (i.e., averaged curve 
of all tree curves) per plot and then per species made it possible to correct each single tree curve (cross-dating) according to the coincidence index, Gleichläufigkeit. In this case, the index was within a range from $71 \%$ to $100 \%$ and averaged $86 \pm 10 \%$.

\subsection{Calculation of Annual Mortality Rate and Stand Volume}

Based on the given number of dead trees, the annual mortality rate $M$ per plot $\left(\% \cdot\right.$ year $\left.^{-1}\right)$ was calculated as follows [29]:

$$
M=1-\left(\frac{N_{1}}{N_{0}}\right)^{1 / t}
$$

where $N_{0}$ and $N_{1}$ are population counts at the beginning and end of the measurement interval, $t$.

Concerning volume assessment, a regression model with tree diameter and height was first developed for each species to predict tree height for those trees for which height was not measured (Figure 1). The resulting equations for Turkey oak $(\mathrm{QC})$, sessile oak $(\mathrm{QP})$ and pedunculated oak $(\mathrm{QR})$ were, respectively:

$$
\begin{aligned}
& \text { Height }_{\mathrm{QC}}=2.6188 \ln \left(\mathrm{DBH}_{\mathrm{QC}}\right)-5.2781 \quad\left(R^{2}=0.69\right) \\
& \text { Height }_{\mathrm{QP}}=2.1933 \ln \left(\mathrm{DBH}_{\mathrm{QP}}\right)-4.239 \quad\left(R^{2}=0.66\right) \\
& \text { Height }_{\mathrm{QR}}=2.2567 \ln \left(\mathrm{DBH}_{\mathrm{QR}}\right)-4.1434 \quad\left(R^{2}=0.55\right)
\end{aligned}
$$

The McFadden's R-squared $R^{2}$ revealed a relatively high correlation between the data and the equation for each species. Second, the stand volume per plot $V$ $\left(\mathrm{m}^{3} \cdot \mathrm{ha}^{-1}\right)$, used as a proxy of the productivity, was calculated as follows [30]:

$$
V=\sum \frac{\pi \cdot d^{2} \cdot h}{4 \cdot S}
$$

where $\pi=3.14, d$ is the $\mathrm{DBH}, h$ is the height and $S$ is the plot size.

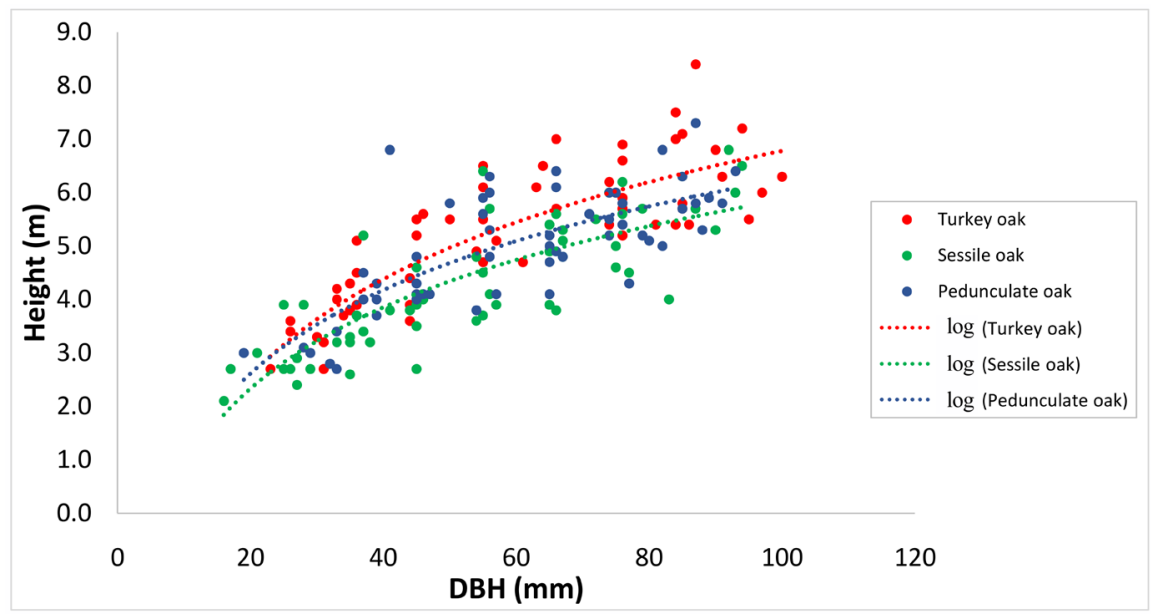

Figure 1. Height over Diameter at Breast Height (DBH) curves per species. Red, blue and green correspond to Turkey oak (QC), sessile oak (QP) and pedunculate oak (QR), respectively. Curves were obtained by a logarithm trendline tool. 


\subsection{Calculation of Basal Area Increment}

Based on ring widths, the basal area increment (BAI) ( $\mathrm{mm}^{2} /$ year), i.e., cross-section area at $1.1 \mathrm{~m}$, was calculated for each year from 2009 to 2015 for each tree on the basis of the calculated basal area BA $\left(\mathrm{mm}^{2}\right)$ defined as follows:

$$
\mathrm{BA}=\pi \cdot r^{2}
$$

where $\pi=3.14$ and $r$ is the stem radius. The BAI was then averaged per species.

\subsection{Characterisation of Pointer Years and Calculation of Drought Indices}

In order to characterise drought intensity and thus define pointer years, meteorological parameters (monthly precipitation, potential evapotranspiration, soil moisture, etc.) were taken from the database of the Climate Data Centre provided by the Deutscher Wetterdienst website [31]. The Standardised Precipitation Index for 3 months (SPI-3 months) was calculated using different steps. First, the SPI was calculated as follows on a monthly basis for the growing season only (from April to September) to avoid a bias [32] [33]:

$$
\operatorname{SPI}(x)=\frac{P(x)-\mu(6 x)}{\sigma(6 x)}
$$

where $P$ is the precipitation for a given month $x, \mu$ is the average for 6 months $x$ and $\sigma$ is the standard deviation for 6 months $x$. Then, in order to consider only the peak in summer, the SPI was averaged for the period from June to August. In addition to this index, water balance WB (mm) was calculated as follows [34]:

$$
\mathrm{WB}(x)=P(x)-\operatorname{PET}(x)
$$

where $P$ is the precipitation and PET is the potential evapotranspiration for a given month $x$. Like the SPI, the calculation of WB focused only on the growing season. The final WB then consisted of the sum of the three months of high summer (June to August).

A radial growth analysis was also performed to calculate drought indices according to [35]. Three Lloret indices were required to characterise growth reaction to drought: resistance, recovery and resilience. Due to the lack of data, we focused on the resistance index RT in 2013 and 2015, and the recovery index RC and the resilience index RS only in 2013. Since the length of the ring series was limited to only eight years, a detrending could not be carried out. The Lloret indices were therefore calculated only at the one-year time level, i.e., only one year prior to drought and one year after drought were considered. Resistance was defined as the ratio between the radial growth performance during (Dr) and prior to (PreDr) the drought year.

$$
\mathrm{RT}=\frac{\mathrm{Dr}}{\mathrm{PreDr}}
$$

Recovery was defined as the ratio between the performance after (PostDr) and during the disturbance. 


$$
\mathrm{RC}=\frac{\text { PostDr }}{\mathrm{Dr}}
$$

Resilience was defined as the ratio between the radial growth performance after and prior to the drought year.

$$
\mathrm{RS}=\frac{\text { PostDr }}{\text { PreDr }}
$$

The three indices were calculated for each tree, based on raw ring width curves.

\subsection{Statistical Analysis}

Statistical analysis was performed with $\mathrm{R}$ software. The plot was the experimental unit: each analysis was conducted with four replicates. Comparisons of quantitative target variables (stand volume, annual mortality rate, ring widths, Lloret index) among oak species (independent qualitative variable) were performed using repeated-measures ANOVA $(\operatorname{aov}()$ function) and Tukey's post hoc test (TukeyHSD() function) or the paired post-hoc t-test (pairwise.t.test() function), with a significance level of $5 \%$. To check the linear model created with the function $\operatorname{lm}()$, the absence of outliers was verified with a graph (using the plot() function). The assumptions of normal distribution, homoscedasticity and independence were then verified a posteriori using the model residuals (i.e., sample of error terms) and the plot() function. Normal distribution was verified by plotting the quantiles of the distribution of the standardised residuals against those of the standard normal distribution (quantile-quantile plot). Normal distribution was assumed if the plot followed the reference line $(1,1)$. Homoscedasticity was verified by plotting the model residuals against the predicted values. Homogeneous variance was assumed if the residuals were approximately fairly displayed around the reference line $(y=0)$ across the full range of predicted values. Independence was verified using Pearson correlation coefficients, helped by the cor.test () function, where $\mathrm{t}=\rho \sqrt{ }\left((\mathrm{n}-2) /\left(1-\rho^{2}\right)\right)$, where $\rho$ is the correlation and $\mathrm{n}$ is the sample size. The distribution of $\mathrm{t}$ is a Student's $\mathrm{t}$-distribution with degrees of $\mathrm{n}-2$ freedom, under the null hypothesis of complete independence [36]. Independence was assumed if the p-value of the test was greater than $5 \%$ (i.e., a Pearson value of 0 ).

\section{Results}

\subsection{Stand Volume and Mortality}

The stand volume was not significantly different between Turkey oak and pedunculate oak (means of $6.1 \mathrm{~m}^{3} \cdot \mathrm{ha}^{-1} \pm 0.6$ and $5.9 \mathrm{~m}^{3} \cdot \mathrm{ha}^{-1} \pm 1.3$, respectively), but both had a higher stand volume than sessile oak $\left(4.0 \mathrm{~m}^{3} \cdot \mathrm{ha}^{-1} \pm 0.9\right.$ on average) (Figure 2(a)). The total average stand volume was $5.0 \mathrm{~m}^{3} \cdot \mathrm{ha}^{-1} \pm 0.9$ for the three species.

The annual mortality rate per plot was not significantly different between Turkey oak and pedunculate oak (means of $0.3 \% \cdot$ year $^{-1} \pm 0.3$ and $0.4 \% \cdot$ year $^{-1} \pm 0.2$, 


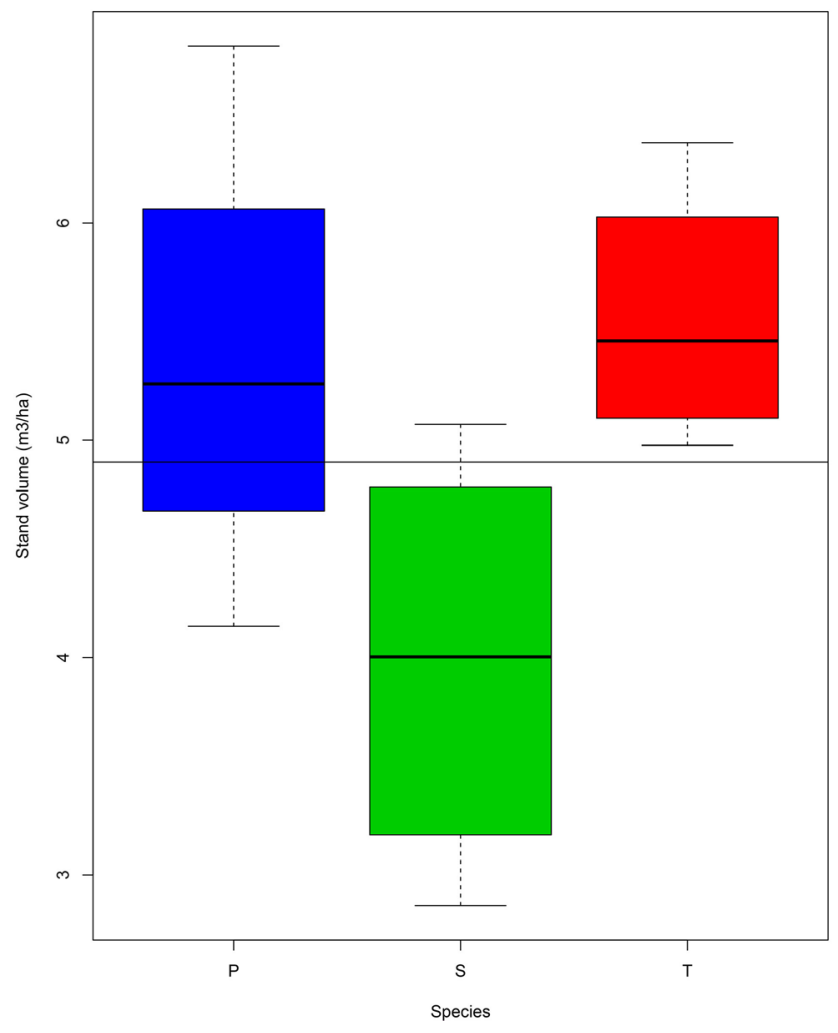

(a)

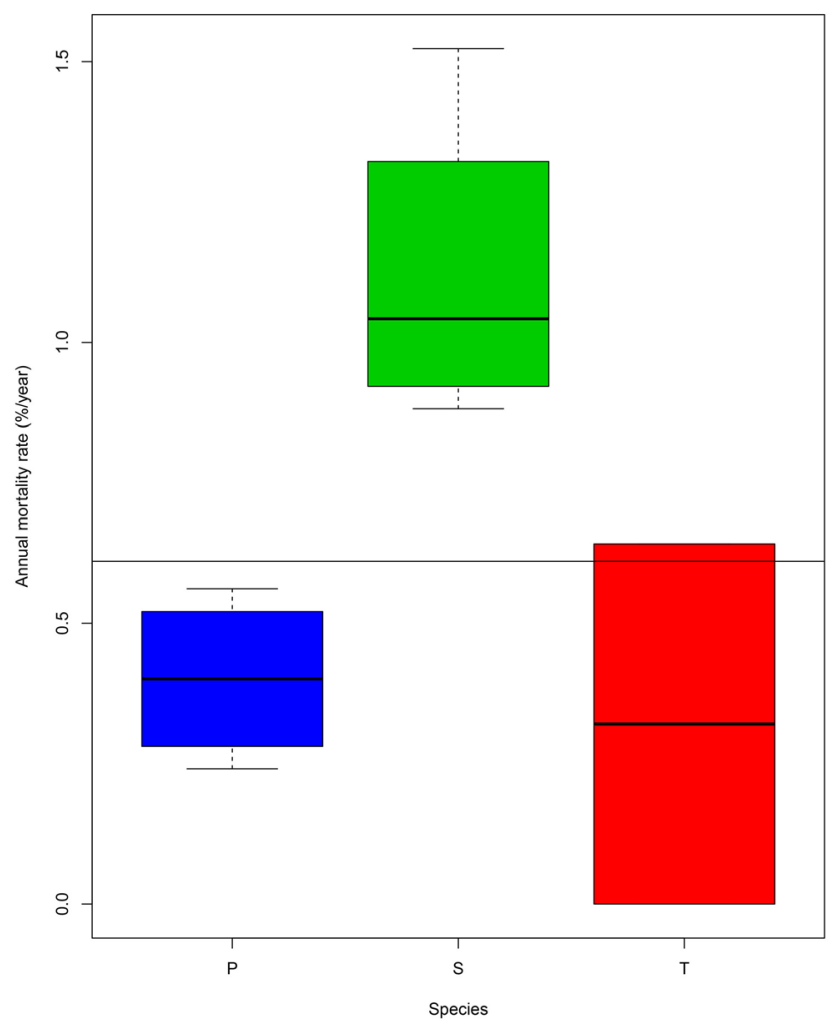

(b)

Figure 2. Boxplots representing stand volume (a), annual mortality rate (b) and fork occurrence (c) for Turkey oak (red), sessile oak (green) and pedunculate oak (blue). The extremities of the box represent the interquartiles and the dark line inside represents the median of the given parameter. The whiskers correspond to the minimum and maximum values of the given parameter. The thin horizontal line represents the total average of the given parameter.

respectively) (Figure 2(b)). Regarding mortality rates, Turkey oak presented a higher variation in mortality rate than pedunculate oak $\left(0 \%-0.6 \% \cdot\right.$ year $^{-1}$ vs. $0.3 \%$ - $0.5 \% \cdot$ year $\left.^{-1}\right)$ and the lowest level of $0 \% \cdot$ year $^{-1}$ compared to the native species. The highest level of mortality was observed for sessile oak (mean of $1.1 \% \cdot y^{-1} \mathrm{ear}^{-1}$ $\pm 0.3)$ Nonetheless, $1.5 \% \cdot$ year $^{-1}$ was a low level but significantly higher than the mortality rate observed for pedunculate oak and Turkey oak. The total average mortality rate per plot for the three species was $0.6 \% \cdot$ year $^{-1} \pm 0.3$.

\subsection{Radial Growth Response to Drought}

The tree-ring analysis revealed three years with distinct growth depressions: 2009, 2013 and 2015 (Figure 3). On the one hand, mean ring width curves already presented a flattening, given the fact that a relatively stable level of growth ( $7 \mathrm{~mm}$ for Turkey oak and $5-6 \mathrm{~mm}$ for the native species) was obtained as of 2012 (Figure 3(a)). On the other hand, mean BAI curves presented a strongly increasing, almost exponential trend up to 2014 (Figure 3(b)). Considering ring widths, the difference between Turkey oak and the two native species was pronounced as of 2013. Taking the mean BAI curves into account, the difference between Turkey oak and the two native species was pronounced as of 2014. 


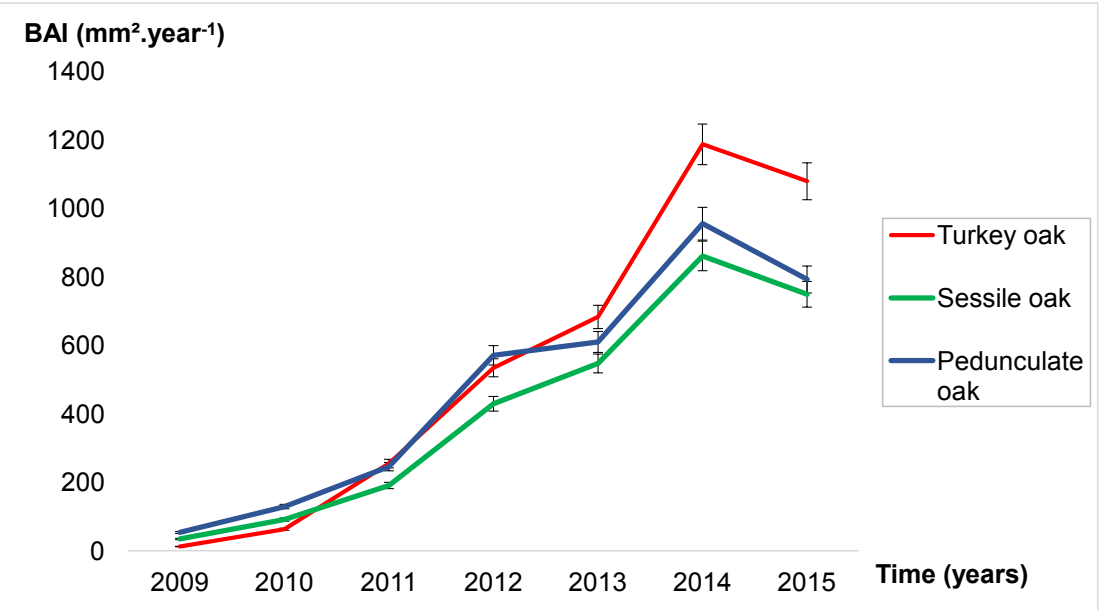

(a)

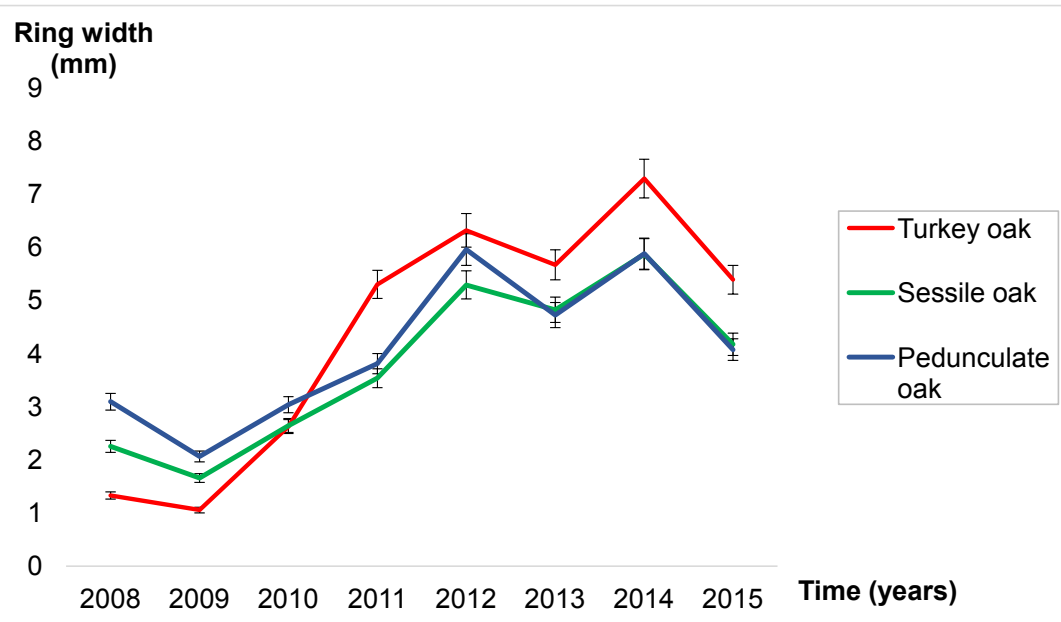

(b)

Figure 3. Mean raw curve of radial growth in ring width (a) and in basal area increment (b) for each species. Red, blue and green correspond to Turkey oak (QC), sessile oak (QP) and pedunculate oak $(\mathrm{QR})$, respectively. Bars show significant differences between species for a given year (ANOVA, $\alpha=0.05$ ).

The Lloret resistance index was not significantly different between species for 2013 (Figure 4(a)) and 2015 (Figure 4(b)). However, the three oak species presented a lower total average in 2015 (0.7) compared to 2013 (0.9). The recovery in 2013 was not significantly different between the three oak species and presented a high variation for Turkey oak (Figure 4(c)). The resilience of Turkey oak in 2013 was significantly higher than that of pedunculate oak (Figure 4(d)).

\subsection{Characterisation of Pointer Years on the Basis of Drought Indices}

The SPI-3 months of 2009, 2011 and 2012 were defined as wet years; those of 


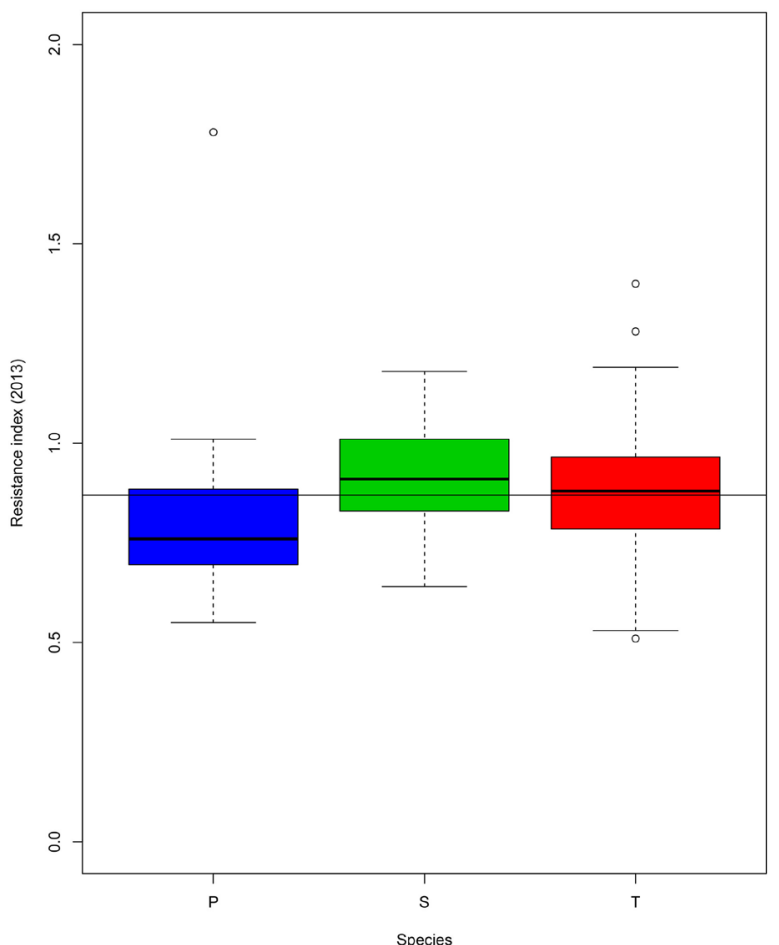

(a)

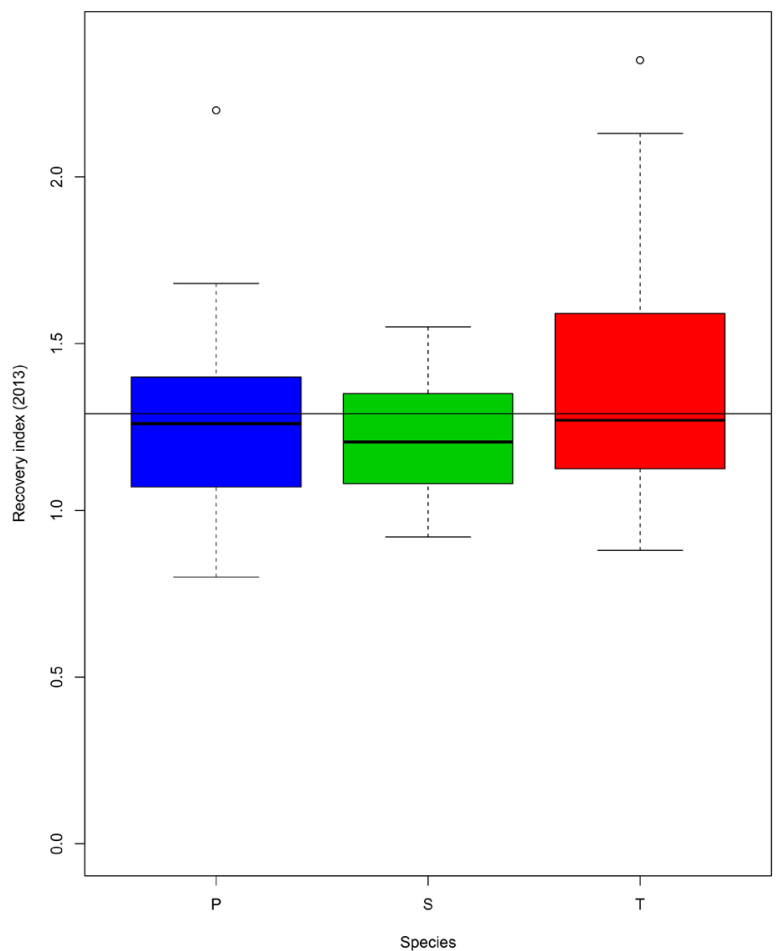

(a)

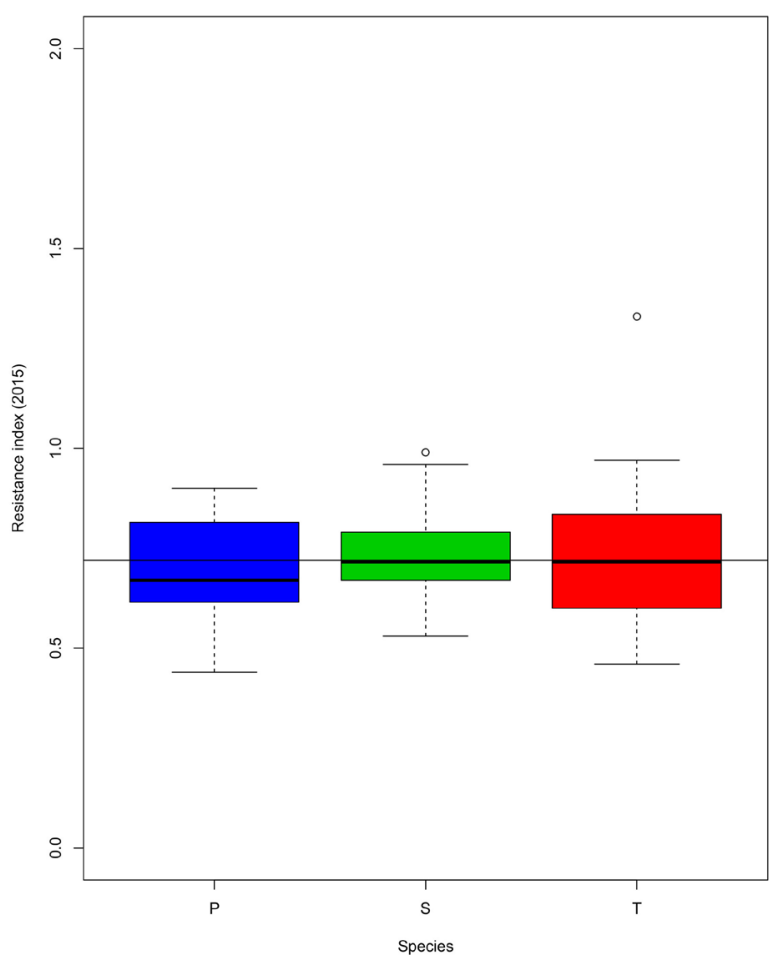

(b)

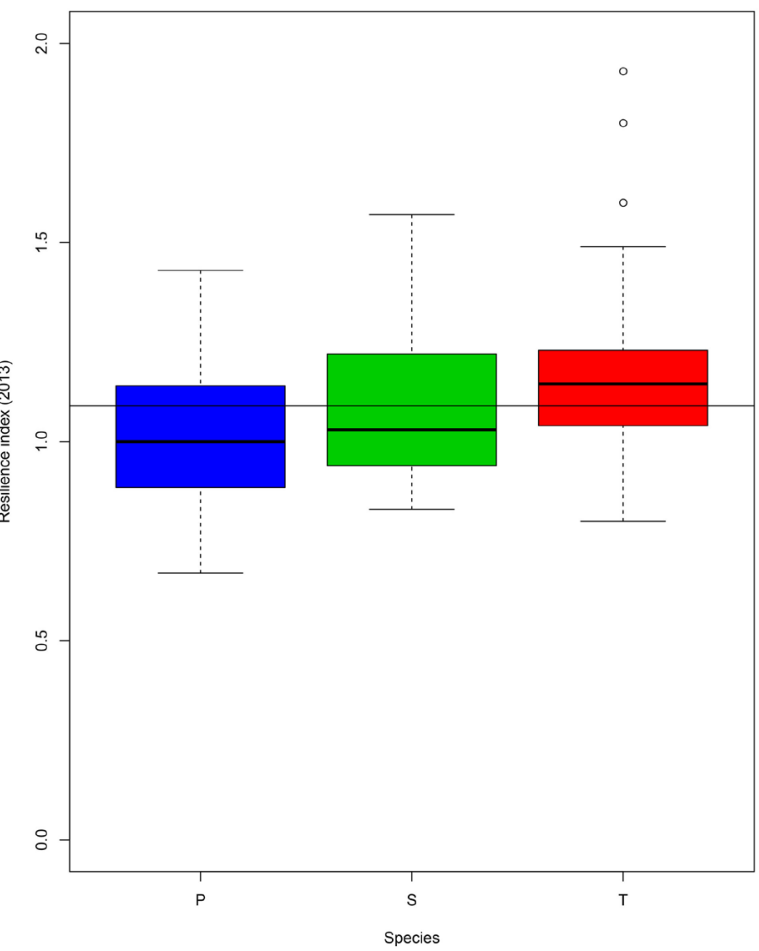

(b)

Figure 4. Boxplots representing the Lloret resistance index for 2013 (a) and 2015 (b), the Lloret recovery index for 2013 (c) and the Lloret resilience index for 2013 (d) for Turkey oak (red), sessile oak (green) and pedunculate oak (blue), on the basis of mean ring width curves. The extremities of the box represent the interquartiles and the dark line inside represents the median of the given parameter. The whiskers correspond to the minimum and maximum values of the given parameter. The thin horizontal line represents the total average of the given parameter. 
2008, 2010 and 2014 as normal years; and those of 2013 and 2015 as dry years (Figure 5(a)). The water balance curve for the annual high summer (sum of three months, i.e., from June to August) confirmed that the "Mooswald" plantations were suffering from a lack of water in 2013 (water deficit of $15.8 \mathrm{~mm}$ ) and especially in 2015 (water deficit of $85.7 \mathrm{~mm}$ ) (Figure 5(b)). 2014 was a rainy year (water surplus of $173.1 \mathrm{~mm}$ ). Between 2008 and 2012, the water balance was stable, remaining close to $+40 \mathrm{~mm}$. Considering the period 2000-2015, 2014 and 2015 presented opposing extremes.

\section{Discussion}

\subsection{Mortality and Growth in Response to Severe Drought}

Mortality of Turkey oak and pedunculate oak was low, whereas a significantly higher mortality rate was observed in sessile oak (Figure 2(b)). However, the maximum level of mortality was $1.5 \%$ (sessile oak), which was very low from the silvicultural point of view. In the case of plant loss up to $20 \%$ [37], replacement planting is usually performed. This is why replacement planting will not be necessary in the "Mooswald" experiment and the mortality rate can be neglected. However, the slightly lower mortality of Turkey oak could be a sign of a slightly better adaptation of the "Mooswald" afforestation to the site conditions.

Regarding stand volume as a proxy of productivity, sessile oak presented a significantly lower stand volume than Turkey oak and pedunculate oak (Figure $2(a))$. This lower stand volume can be explained as a result of its slower growth compared to the other species (Figure 1 and Figure 2). The slow growth of sessile oak can be interpreted as a lack of adaptation to site conditions or as a common growth trend. On the one hand, sessile oak is known to be more characteristic of sites on slopes and hilltops, in contrast to pedunculate oak that is more typical of wet lowlands like the "Mooswald" site [10]. On the other hand, the study of [38] on the Hardt National Forest in France revealed that pedunculate oak is more productive than sessile oak at the young stage, but that the trend is reversed after 25 years. Concerning Turkey oak (Figure 1 and Figure 2), it presented a high growth performance, especially during drought years such as 2015. This result is supported by two studies performed in 2014 at the same site. Their findings showed that Turkey oak displayed a trend (insignificant) towards higher Water Use Efficiency (WUE, i.e., the ratio between carbon assimilation and transpiration rate) with a higher rate of photosynthesis for all levels of soil water availability [39] and higher fine root biomass [40] than pedunculate oak. More precisely, regarding the latter, [40] demonstrated that Turkey oak had more fine root biomass in deeper layers of the soil and less in the upper soil compared to pedunculate oak. This pattern can promote higher resistance to drought for Turkey oak and, consequently, better growth performance under dry conditions. In addition, radial growth analysis revealed a trend towards a higher fraction of earlywood with big vessels for Turkey oak compared to the native oaks. This could be an adaptation to the growing conditions in southeast 


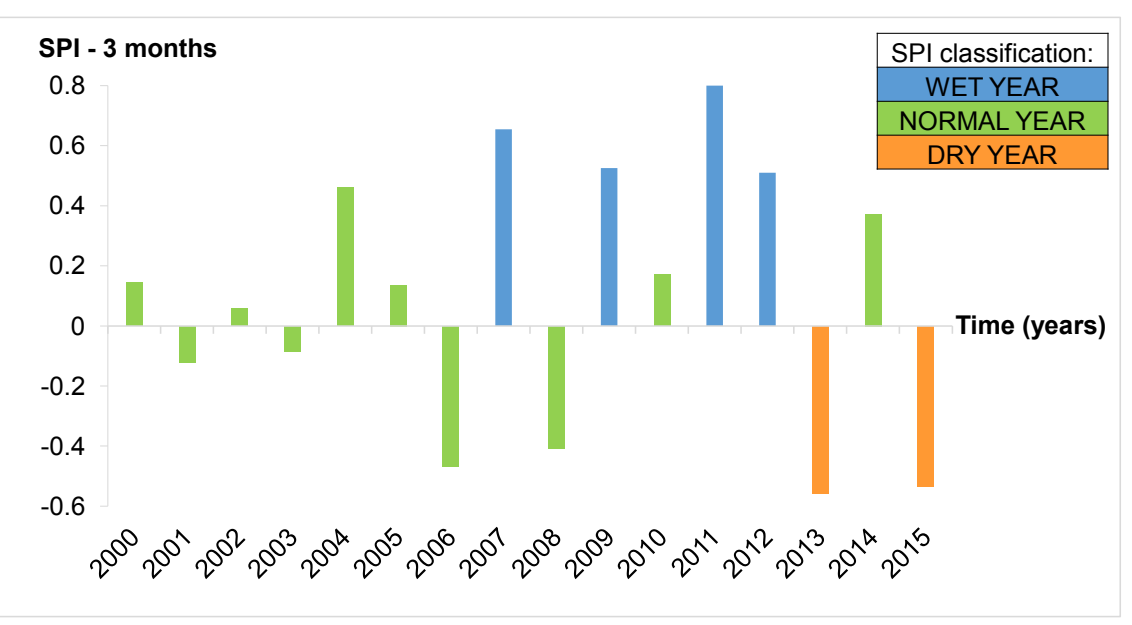

(a)

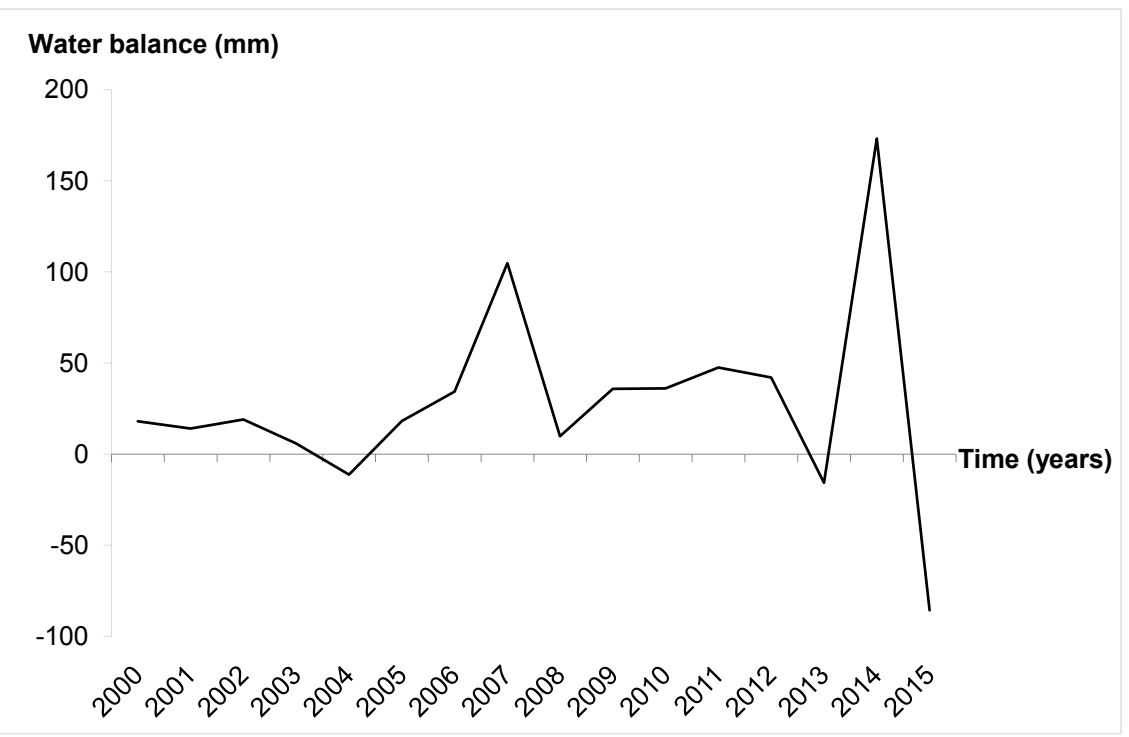

(b)

Figure 5. Histogram of the Standardized Precipitation Index-3 months (SPI-3 months) (a), indicating the wet, normal and dry years, and the water balance curve (b) of the high summer (monthly sum from June to August) from 2000 to 2015.

Europe: Turkey oak grows very fast in spring and early summer and makes more efficient use of the favourable conditions during this period (water availability in the soil, temperature), whereas its growth in mid and late summer slows down under southeast European site conditions (summer heat, drought). Nevertheless, a more precise quantitative analysis would be necessary to assess the fraction of earlywood and explain the drought response observed. The high growth performance of Turkey oak could also be explained by a lesser sensitivity (or maybe a non-sensitivity) to the existing caterpillar attacks (such as oak processionary moth) [10] [11]. Herbivory is an important factor for the impairment of growth, especially for oaks, which will increase with climate change [41].

In a methological overview, the comparison between growth dynamics observed for these very young oak stands and results from the literature was im- 
possible: no volume or yield tables exist for young stands, and other data (such as forest inventories) exist only for trees of more than 10 years of age.

\subsection{Resistance and Resilience to Radial Growth Depressions in Response to Drought}

During the growth period 2008-2015, three growth depressions were observed: 2009, 2013 and 2015 (Figure 3(a)). However, 2009 was rejected of the analysis assuming that this depression might have been an internal signal. Indeed, planted trees came from a nursery (good growing conditions) and it can take from one to three years for them to adapt to environmental conditions [42]. Thus, taking account of the fact that 2009 was a wet year as well (Figure 5), this depression might have been caused by a planting shock. Concerning the two other depressions, the three oak species presented higher growth depression in 2015 compared to 2013 (Figure 3). The drought in 2015 (water deficit of 85.7 $\mathrm{mm}$ ) was indeed more severe than the drought in 2013 (water deficit of 15.8 $\mathrm{mm}$ ), and as severe as the drought in 2003 (Figure 5). Figure 6 shows that the monthly groundwater table level in the Waltershofen-Freiburg station (close to the "Mooswald" afforestation) in 2003 (205.5 m above sea level) was similar to that in 2015 (205.6 m above sea level) and both were at the lowest level observed during the period 2001-2015. Thus, it can be concluded from this result that the lower resistance observed in 2015 of the three oak species than the one in 2013 (Figure 4) resulted from higher growth depression due to more severe drought in 2015. In addition, the drought in 2013 might still have had an impact on growth during the drought in 2015 (only two years in between), which can also explain the higher growth depression in 2015. This last point was also important

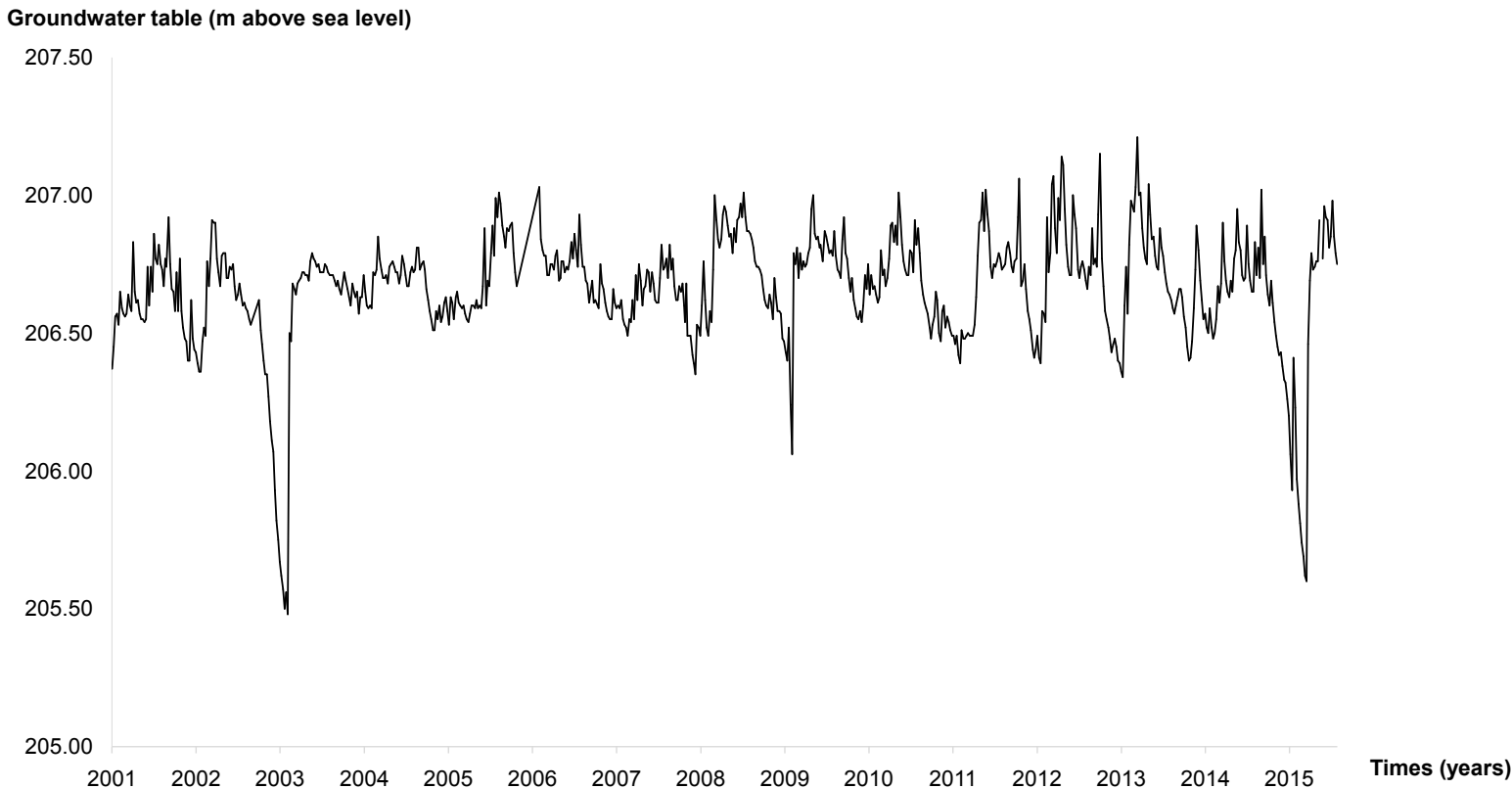

Figure 6. Monthly groundwater table level curve at the Waltershofen-Freiburg station, close to the "Mooswald" afforestation (based on data from LUBW, 2016). 
when focusing on the recovery after 2013. Indeed, in order to evaluate it, several normal growth years after 2013 would have been necessary, which was not the case in this study (only 2014 between two severe droughts). More generally, all the Lloret indices were calculated taking only one year before and one year after the disturbance into account due to the shortness of the chronologies, which was not a classical method. In fact, the calculation is usually performed on long series with a constant growth before and also after the disturbance. For example, [35] studied series of 250 years, which had six drought periods with 35 - 60 years of low growth in between.

Comparing the three oak species, no significant differences in resistance to drought were observed between species (Figure 4(a) and Figure 4(b)). This was surprising since Turkey oak is considered to be more drought-resistant than pedunculate oak or sessile oak [11] [13] [43] [44]. Focusing only on the native species, sessile oak presented a trend of higher resistance (not statistically significant) compared to pedunculate oak. On the one hand, this trend is supported by different studies [18] [45], but the use of only one provenance per species does not make it possible to generalise these differences in drought tolerance between the two species. Variations within species may be greater than the interspecific variation and, consequently, different provenances must be included in further investigations. On the other hand, contradictory evidence presents sessile oak as being as drought-resistant as pedunculate oak [8] [46].

Concerning resilience to drought, pedunculate oak had an unexpected weak level (Figure 4(d)). This species is the one naturally found in lowlands [10] and the most favoured in abandoned fertilised lands such as the "Mooswald" afforestation because it has more pioneer characteristics compared to the two other species [37]. With shallower fine roots than Turkey oak, linked to a lower rate of photosynthesis [39] and a lower WUE [22] than both of the other oak species discussed here, it is possible that pedunculate oak was less resilient to radial growth depression in response to drought in 2013. More precisely, [22] demonstrated that a low WUE was characteristic of pioneer species, and interspecific differences in WUE between pedunculate oak and sessile oak (seedlings as well as adult trees) are genetic due to a maximisation of carbon gain. Indeed, pedunculate oak tends to maximise initial growth associated with a low adult tree survival following drought (pioneer characteristic), in contrast with sessile oak (slow growth but long-term survival of adult trees). This can be correlated with the growth performance trend observed in Figure 1.

\subsection{Discussion of Methods and Limits of the Study}

The analysis of our tree chronologies was difficult due to their shortness and the non-suitable tools such for detrending. Indeed, the series is detrended in order to remove age effects. This makes it possible to estimate and remove the tree's natural biological growth trend for each ring width curve and to increase the importance of slow growth. Nevertheless, our tree ring chronologies made it difficult to apply this commonly used tool on radial growth curves. First, the chro- 
nologies were short: only seven years were devoted to the first years of the tree growth characterised by a steep slope in growth dynamics. The software (ARSTAN, dplR-package in R, SPSS) was not adapted to these short chronologies. Indeed, this typical software generally manages series of about $100-400$ years (decade-per-decade). Second, regarding the raw ring width curves (Figure 3(a)), the three growth depressions made it impossible to develop a growth trend, especially with the high depression in 2015 that was the last year of the chronologies. In contrast, an almost exponential trend was observed in BAI curves (Figure 3(b)) that seemed to be easier to detrend. The method consisted of using a spline or drawing an exponential model $(\mathrm{Y}=\alpha \cdot \mathrm{e}(-\beta \cdot \mathrm{t})+\delta)$ for each tree curve, but the software that was unsuitable for short chronologies gave aberrant results. On the one hand, the minimum frequency of the spline is greater than seven years. For example, ARSTAN commonly builds splines for series of 128 years, i.e., its normal analysis interval is 1857-1988 [47], and R for series of a minimum of 100 years [48]. On the other hand, SPSS and Excel modules (such as trendline) provide unsuitable exponential models for our purposes.

\section{Conclusion}

The literature presented Turkey oak as being more productive and more drought-resistant than either pedunculate or sessile oak. In the "Mooswald" afforestation, the non-native Turkey oak presented higher stand volume and lower mortality than the native sessile oak, values that are not significantly different from those of native pedunculate oak. Sessile oak was therefore the least productive. However, Turkey oak was not significantly more resistant to drought than the two native oaks, and pedunculate oak was the least resilient to drought. Since our study only focused on a young afforestation, these results are only a trend that must be confirmed at older stand stages. Nevertheless, other parameters should be integrated into future studies such as vitality parameters (e.g., sap conduction, photosynthesis, leaf parameter) and wood anatomy analysis (e.g., detection of active rings, proportion of earlywood). Investigation in young stands must continue and monitoring must be improved and done at an earlier stage in order to extend databases and to implement suitable forest management. Tools such as dendrochronological software must be further improved and adapted to fit research on shorter year ring series as well.

\section{Highlights}

Drought decreases the growth of young pedunculate oak and sessile oak. We only focused on a young afforestation since very few studies have been devoted to this crucial forest establishment phase. Substituting these two native species with Turkey oak could be a solution. Our results are the beginning of further research into this field to implement suitable management of oak forests.

\section{Funding}

This work was supported by the University of Freiburg, the University of Lor- 
raine and the Lorraine Regional Council.

\section{Acknowledgements}

I would like to acknowledge Martin Köhler and Jürgen Bauhus for their supervision and helpful suggestions during my trainee position at the Chair of Silviculture at the University of Freiburg. I am also grateful to Marielle Brunette for her technical support and her helpful suggestions; to Hernan Montero, Elise Héral, Leana Gooriah, Florian Schnabel, Magdalena Gerhardt and Jörg Kunz for their technical support; and to Georgios Skiadaresis, Gwënaëlle Gibaud, Herma Labille, Penny Whitehouse and Céline Caubert for their external help. I acknowledge all the reviewers. The UMR BETA is supported by a grant overseen by the French National Research Agency (ANR) as part of the "Investissements d'Avenir" program (ANR-11-LABX-0002-01, Lab of Excellence ARBRE).

\section{References}

[1] Kändler, G. and Cullmann, D. (2016) Regionale Auswertung der Bundeswaldinventur 3-Regierungsbezirk Freiburg. Report, Forstliche Versuchs- und Forschungsanstalt, Baden-Württemberg.

[2] Gaertig, T., et al. (2002) The Impact of Soil Aeration on Oak Decline in Southwestern Germany. Forest Ecology and Management, 159, 15-25. https://doi.org/10.1016/S0378-1127(01)00706-X

[3] Fischer, R. and Hartmann, G. (1999) Decline of European and Sessile Oak. In: $U N / E C E$ and EC. Forest Conditions in Europe. Executive Report, Geneve, Brussels, 7-9.

[4] Pachauri, R.K., Meyer, L.A., et al., Eds. (2014) Climate Change 2014: Synthesis Report. Contribution of Working Groups I, II and III to the Fifth Assessment Report of the Intergovernmental Panel on Climate Change. IPCC 2014, Geneva, 151.

[5] Spathelf, P., et al. (2014) Climate Change Impacts in European Forests: The Expert Views of Local Observers. Annals of Forest Science, 71, 131-137. https://doi.org/10.1007/s13595-013-0280-1

[6] Lorenz, M. and Becher, G. (2012) Forest Condition in Europe: 2012 Technical Report of ICP Forests. ICP Forests, Hamburg. http://literatur.ti.bund.de/digbib_extern/dn051886.pdf

[7] Santini, A., et al. (1994) Preliminary Dendroecological Survey on Pedunculate Oak (Quercus robur L.) Stands in Tuscany (Italy). Annales des Sciences Forestières, 51, 1-10. https://doi.org/10.1051/forest:19940101

[8] Bréda, N., et al. (1993) Field Comparison of Transpiration, Stomatal Conductance and Vulnerability to Cavitation of Quercus petraea and Quercus robur under Water Stress. Annales des Sciences Forestières, 50, 571-582. https://doi.org/10.1051/forest:19930606

[9] Neophytou, C. and Michiels, H.G. (2013) Upper Rhine Valley: A Migration Crossroads of Middle European Oaks. Forest Ecology and Management, 304, 89-98. https://doi.org/10.1016/j.foreco.2013.04.020

[10] Eaton, E., et al. (2016) Quercus robur and Quercus petraea in Europe: Distribution, Habitat, Usage and Threats. In: San-Miguel-Ayanz, J., et al., Eds., European Atlas of Forest Tree Species, Publication Official EU, Luxembourg, 160-163.

[11] De Rigo, D., et al. (2016) Quercus cerris in Europe: Distribution, Habitat, Usage and 
Threats. In: San-Miguel-Ayanz, J., et al., Eds., European Atlas of Forest Tree Species, Publication Official EU, Luxembourg, 148-149.

[12] Rameau, J.-C., et al. (2012) Flore Forestière Française: Guide Ecologique Illustré. Vol. 1, Plaines et Collines. Institut pour le Développement Forestier, Paris, 1792 p.

[13] Cutini, A. (1997) Drought Effects on Canopy Properties and Productivity in Thinned and Unthinned Turkey Oak Stands. Plant Biosystems, 131, 59-65. https://doi.org/10.1080/11263504.1997.10654167

[14] Di Filippo, A., et al. (2010) Climate Change and Oak Growth Decline: Dendroecology and Stand Productivity of a Turkey Oak (Quercus cerris L.) Old Stored Coppice in Central Italy. Annals of Forest Science, 67, 706-706. https://doi.org/10.1051/forest/2010031

[15] Kätzel, R., et al. (2012) Untersuchungen zu Vitalität, Wuchsleistung und Holzqualität von Zerr-Eichen (Quercus cerris L.) im Kommunalwald von Prenzlau. Archiv für Forstwesen und Landschaftsökologie, 46, 125-132.

[16] Erteld, W. (1953) Ertragstafelauszüge für den Gebrauch in der Praxis. Vol. 2, Neumann Verlag, Radebeul.

[17] Ellenberg, H. and Leuschner, C. (2010) Vegetation Mitteleuropas mit den Alpen. 6th Edition, Eugen Ulmer Verlag, Stuttgart.

[18] Günthardt-Goerg, M.S. (2012) Foliage Response of Young Central European Oaks to Air Warming, Drought and Soil Type. Plant Biology, 15, 185-197. https://doi.org/10.1111/j.1438-8677.2012.00665.x

[19] Gallé, A., et al. (2007) Photosynthetic Performance and Water Relations in Young Pubescent Oak (Quercus pubescens) Trees during Drought Stress and Recovery. New Phytologist, 174, 799-810. https://doi.org/10.1111/j.1469-8137.2007.02047.x

[20] Thomas Fernandez, R., et al. (1997) Drought Response of Young Apple Trees on Three Rootstocks. II. Gas Exchange, Chlorophyll Fluorescence, Water Relations, and Leaf Abscisic Acid. Journal of the American Society for Horticultural Science, 122, 841-848.

[21] Buhk, C., et al. (2016) On the Influence of Provenance to Soil Quality Enhanced Stress Reaction of Young Beech Trees to Summer Drought. Ecology and Evolution, 6, 8276-8290. https://doi.org/10.1002/ece3.2472

[22] Ponton, S., et al. (2002) Comparison of Water-Use Efficiency of Seedlings from Two Sympatric Oak Species: Genotype $\times$ Environment Interactions. Tree Physiology, 22, 413-422. https://doi.org/10.1093/treephys/22.6.413

[23] Thomas, F.M. (2000) Growth and Water Relations of Four Deciduous Tree Species (Fagus sylvatica L., Quercus petraea [MATT.] LIEBL., Q-pubescens WILLD., Sorbus aria [L.] CR.) Occurring at Central-European Tree-Line Sites on Shallow Calcareous Soils: Physiological Reactions of Seedlings to Severe Drought. Flora, 195, 104-115. https://doi.org/10.1016/S0367-2530(17)30958-1

[24] Villinger, E. (2008) Geologie der Freiburger Bucht. In: Körner, H., Ed., Die Mooswälder. Natur-und Kulturgeschichte der Breisgauer Bucht, Lavori, Freiburg, $15-42$.

[25] Hügin, G. (1990) Die Mooswälder der Freiburger Bucht: Wahrzeichen einer alten Kulturlandschaft. Gestern-heute ... und morgen? Landesanstalt für Umweltschutz Baden-Württemberg, Karlsruhe, 88 p.

[26] Landesanstalt für Umwelt, Messungen und Naturschutz Baden-Württemberg (LUBW), c2015. Grundwasser. http://www4.lubw.baden-wuerttemberg.de/servlet/is/2693/ 
[27] Ningre, F. (1997) Une Définition Raisonnée de la Fourche du Jeune Hêtre. Revue forestière française, 49, 32-40.

[28] FAO (2002) National Forest Inventory: Field Work Manual. http://www.fao.org/3/a-ae578e.pdf

[29] Sheil, D., et al. (1995) The Interpretation and Misinterpretation of Mortality Rate Measures. Journal of Ecology, 83, 331-333. https://doi.org/10.2307/2261571

[30] Bowers, S., et al. (1989) Stand Volume and Growth: Getting the Numbers. The Woodland Workbook, Forest Measurement. Oregon State University, Corvallis, 26 p.

http://www.cof.orst.edu/cof/fs/kpuettmann/FS\%20533/2007/Volume\%20and\%20gr owth\%20measurements.pdf

[31] Wetterdienst DWD. CDC (Climate Data Centre). http://www.dwd.de/EN/climate_environment/cdc/cdc_node.html

[32] Svoboda, M., et al. (2012) Standardized Precipitation Index User Guide. World Meteorological Organization, Geneva, $24 \mathrm{p}$.

[33] McKee, T.B., et al. (1993) The Relationship of Drought Frequency and Duration to Time Scales. 8th Conference on Applied Climatology, Anaheim, 17-22 January 1993, 6 p. http://clima1.cptec.inpe.br/ rclima1/pdf/paper_spi.pdf

[34] Allaire, M.-H. (1970) Les Bilans Hydriques. Bioclimatology Department, INRA, 19-35.

[35] Lloret, F., et al. (2011) Components of Tree Resilience: Effects of Successive Low-Growth Episodes in Old Ponderosa Pine Forests. Oikos, 120, 1909-1920. https://doi.org/10.1111/j.1600-0706.2011.19372.x

[36] Rahman, N.A. (1968) A Course in Theoretical Statistics. Charles Griffin and Company, London.

[37] Sardin, T. (2008) Chênaies Continentales. Guide des Sylvicultures. Office National des Forêts, 456 p.

[38] Bréda, N. (1998) Analyse Rétrospective de la Croissance Radiale des Chênes de la Forêt Domaniale de la Harth. Scientific Report of ONF/INRA Convention. http://prodinra.inra.fr/record/25989

[39] Herpich, J. (2014) Feldstudie zum Vergleich der Wassernutzungseffizienz (WUE) von Jungen, Heimischen und Nichtheimischen Eichen. Master Thesis, Forest Research, University Albert-Ludwigs, Freiburg, 66 p.

[40] Modrow, T. (2014) Feldstudie zum Vergleich von Feinwurzelparametern Junger Stiel-und Zerreichen. Bachelor Thesis, Forest Research, University Albert-Ludwigs, Freiburg, 76 p.

[41] Desprez-Lousteau, M.L., Marçais, B., Nageleisen, L.M., Piou, D. and Vannini, A. (2006) Interactive Effects of Drought and Pathogens in Forest Trees. Annals of Forest Science, 63, 597-612. https://doi.org/10.1051/forest:2006040

[42] Grossnickle, S.C. (2005) Importance of Root Growth in Overcoming Planting Stress. New Forests, 30, 273-294. https://doi.org/10.1007/s11056-004-8303-2

[43] Mészaros, I. (2007) Leaf Growth and Photosynthetic Performance of Two Co-Existing Oak Species in Contrasting Growing Seasons. Acta Silvatica et Lignaria Hungarica, 3, 7-20.

[44] Tognetti, R., et al. (1996) Comparison of Sap Flow, Cavitation and Water Status of Quercus petraea and Quercus cerris Trees with Special Reference to Computer Tomography. Plant, Cell and Environment, 19, 928-938. 
https://doi.org/10.1111/j.1365-3040.1996.tb00457.x

[45] Schmull, M. and Thomas, F.M. (2000) Morphological and Physiological Reactions of Young Deciduous Trees (Quercus robur L., Q. petraea [Matt.] Liebl., Fagus sylvatica L.) to Waterlogging. Plant and Soil, 225, 227-242.

https://doi.org/10.1023/A:1026516027096

[46] Epron, D. and Dreyer, E. (1993) Long-Term Effects of Drought on Photosynthesis of Adult Oak Trees [Quercus petraea (Matt.) Liebl. and Quercus robur L.] in a Natural Stand. New Phytologist, 125, 381-389.

https://doi.org/10.1111/j.1469-8137.1993.tb03890.x

[47] Holmes, R.L., et al. (1986) Users Manual for Program ARSTAN, in Tree-Ring Chronologies of Western North America: California, Eastern Oregon and Northern Great Basin. Laboratory of TreeRing Research: University of Arizona, Tucson, 50-65.

[48] Bunn, A., et al. (2016) Package “dplR”. Dendrochronology Program Library in R. http://R-Forge.R-project.org/projects/dplr/ 